\title{
Comorbidities in aging patients with sickle cell disease.
}

Samir K. Ballas

Thomas Jefferson University

Follow this and additional works at: https://jdc.jefferson.edu/cardeza_foundation

Part of the Hematology Commons

Let us know how access to this document benefits you

\section{Recommended Citation}

Ballas, Samir K., "Comorbidities in aging patients with sickle cell disease." (2018). Cardeza

Foundation for Hematologic Research. Paper 45.

https://jdc.jefferson.edu/cardeza_foundation/45

This Article is brought to you for free and open access by the Jefferson Digital Commons. The Jefferson Digital Commons is a service of Thomas Jefferson University's Center for Teaching and Learning (CTL). The Commons is a showcase for Jefferson books and journals, peer-reviewed scholarly publications, unique historical collections from the University archives, and teaching tools. The Jefferson Digital Commons allows researchers and interested readers anywhere in the world to learn about and keep up to date with Jefferson scholarship. This article has been accepted for inclusion in Cardeza Foundation for Hematologic Research by an authorized administrator of the Jefferson Digital Commons. For more information, please contact: JeffersonDigitalCommons@jefferson.edu. 


\section{Comorbidities in aging patients with sickle cell disease}

Samir K. Ballas MD FACP

Cardeza Foundation for Hematologic Research, Sidney Kimmel Medical College, Thomas

Jefferson University. Philadelphia PA USA

Correspondence;

Samir K. Ballas MD FACP

Cardeza Foundation for Hematologic Research

1020 Locust Street, Suite 394

Philadelphia PA 19107

E-mail: samir.ballas@jefferson.edu

Phone: 856-745-6380

Fax: 856-795-0809

Abstract word count: 200

Text word count: 4057

Number of pages: 18 excluding References

Number of references: 138

Number of Figures: 2

Number of Tables: 6

Key words: Sickle cell disease, Aging, Comorbidities

Short Title: Comorbidities in Aging Patients with SCD

The author claims no conflict of interest 


\section{Abstract}

Sickle cell disease (SCD) in general and sickle cell anemia in particular is a highly complex disorder both at the molecular and clinical levels. Although the molecular lesion is a single-point mutation, the sickle gene is pleiotropic in nature causing multiple phenotypic expressions that constitute the various complications of the disease. Moreover, despite the fact that SCD is a chronic malady, its manifestations are both acute and chronic. The former include, among other things, the recurrent vaso-occlusive crises (its hallmark) and acute chest syndrome. The chronic complications include most commonly avascular necrosis and leg ulcers. Currently, survival of patients with SCD has improved dramatically thanks to newborn screening, antibiotic prophylaxis, better vaccine, safer blood transfusion and the use of hydroxyurea. It is the advent of these therapies that improved the survival. This improvement, however, introduced a third dimension of the disease: comorbidities that occur in aging people in the general population. There is concern that the gain in survival may be offset by the comorbidities. Thus it is the purpose of this review to identify the comorbidities in the elderly with SCD and differentiate them from the basis disease to implement proper therapies so that better survival could be maintained. 


\section{Introduction}

Survival of patients with sickle cell anemia (SS) has increased progressively since the 1970's. Newborn screening, prophylactic antibiotics, newer vaccines, newer antibiotics, newer analgesics, safer blood transfusion, chelation therapy and hydroxyurea are some of the reasons for this change in longevity [1-4]. Patients with SS in their sixth, seventh or eighth decade have been described previously [5, 6]. In 1994 Platt et al [1] reported that the median age of survival for males with SS was 42 years and for females 48 years, Later the NIH reported that the median age for patients with SS is now in the late 50s approaching the early 60 years (Figure 1). Aging patients with SCD are at risk to develop comorbidities that often occur in the general population at large. The objective of this review is to promote understanding of the known co-morbidities associated with aging patients with SCD as they relate to appropriate management to improve the quality of life of older patients.

\subsection{Aging and SCD}

Old age in the general population usually refers to life expectancy of people beyond what is presumed to be the life expectancy of human beings. Specific definition of old age, however, varies greatly among countries, cultures, habitats, sociologists and gero-psychiatrists. Thus there are official definitions, popular definitions, sub-group definitions, etc. Gerontologists define subgroup definitions in a number of ways [7, 8]. The sub-group definitions that seem to be in common use define young-old (65-74 years), middle- or older-old (75-84 years) and oldest old ( $\geq 85$ years) [8]. These definitions may replace the definition of age by decades (Table 1 ) such as octogenarian (80 - 89 years) for example. 
Treating older patients could be challenging. Patient-physician communication barriers may occur. Assessment of patients' complaints is often difficult resulting in under- or overtreatment especially in patients who have irrational fears about therapeutic agents and/or cognitive changes. Providers may have difficulty to differentiate the signs and symptoms due to SCD from other comorbid conditions or side effects of medications to treat them [9-11]. Moreover, with aging physiologic changes occur that influence the pharmacodynamics and pharmacokinetics aspects of therapeutic medications [12]. With aging the fat/muscle ratio increases thus altering drug distribution, the gastrointestinal motility decreases causing longer transit time, the cardiac output and renal clearance decrease as well. In addition protein binding of drugs decreases thus increasing drug availability and senescence in the central nervous system associated with decreased resilience and increased side effects of medications [12].

\subsection{The Scope of Comorbidities in SCD}

Comorbidity refers to unrelated pathologic or disease processes that occur concomitantly with SCD. Concomitant disorders can be pain or non-pain comorbidities [13]. They may have a negative, positive, or neutral effect on the primary basic sickling process. This is not unique to SCD pain and occurs frequently in other pain disorders. The comorbidities in SCD, however, are polymorbidity or multimorbidity because they encompass both pain and non-pain pathologic processes.

As patients with SCD age, they become more at risk for developing comorbid conditions that were not previously seen or were rare in this patient population. For example, chronic pain, diabetes mellitus, obesity, and end-stage renal disease in SCD are seen more often now than in the 20th century. Cognizance of the complexity of SCD and its polymorbidities and the 
implementation of preventative, educational, counseling, and prompt intervention measures may ameliorate the associated complexities of the disease and improve quality of life for its victims.

Table 2 lists comorbidities that have been reported in SCD at least once. It includes only conditions that have an impact on sickle cell pain and hence, it may not be comprehensive. Most of the comorbidities listed in Table 2 can precipitate VOCs and may have a significant impact on the morbidity and mortality of patients. Details on selected comorbidities are described below and listed according to anatomic and/or pathophysiologic relevance.

\section{Acquired Immune Deficiency Syndrome}

Acquired immune deficiency syndrome may occur concomitantly in patients with SCD [14-19]. It is associated with several pain syndromes [20], but the types of pain syndromes that may arise when SCD and acquired immune deficiency syndrome coexist are not well characterized. At least in some patients, it appears that SCD may ameliorate the human immunodeficiency virus infection, due to host factors of which asplenia before infection may be one [15].

\section{Anecdotal case reports of certain comorbidities}

Certain comorbidities of SCD were anecdotal in nature reported as case reports or mentioned in reviews. These include atrial fibrillation, Parkinson's disease and irritable bowel syndrome [6, 21]. Inflammatory bowel disease was also reported anecdotally in patients with SCD [22, 23]. Terry et al. [22] reported that the prevalence of proctocolitis in patients with SCD is 3 per 1000.

\section{Chronic Pulmonary Complications}


These complications include asthma, chronic obstructive pulmonary disease (COPD), pulmonary restrictive (also known as fibrotic) lung disease, obstructive sleep apnea and pulmonary hypertension. The hallmark of these pulmonary complications is the presence of hypoxia and/or hypoxemia. Accordingly this set of complications could be due to SCD itself or comorbidities due to factors associated with the environment and aging. This dual causality may explain why these complications in SCD are not exactly the same as those in the general population as will be mentioned below.

\subsection{Asthma}

Asthma is a chronic inflammatory disorder characterized by repeated attacks of airway obstruction and symptoms of increased airway responsiveness [24]. It improves symptomatically in children and young adults but often it persists in adults and worsens with age. It is more common among children $(20-70 \%)$ than adults $(20-30 \%)$ and is more common in African Americans [25]. It is associated with increased morbidity and mortality in people with sickle cell anemia [26, 27]. Its diagnosis is based on clinical picture and spirometry showing decreased forced expiratory volume in one second (FEV1).

\subsection{Chronic Obstructive Pulmonary Disease (COPD)}

Chronic obstructive pulmonary disease is a common lung disease with two main types: chronic bronchitis and emphysema. The former type is the one that usually complicates SCD. It is characterized by airflow limitation that is not fully reversible but is usually progressive and associated with an abnormal inflammatory response to noxious particles or gases [28]. It is diagnosed by post-bronchodilator spirometry showing a reduction in the ratio of FEV1/FVC (< $0.70)$. 


\subsection{Chronic Restrictive Lung Disease}

Chronic restrictive (also known as fibrotic) lung disease is characterized by persistent reduction in total lung capacity (TLC) with or without interstitial lung disease accompanied by a reduction in forced vital capacity (FVC) and functional residual capacity, but little change in residual volume. Diagnosed by spirometry showing FVC $<80 \%$ of predicted value or total lung capacity (TLC) $<90 \%$ of predicted value [29]. Patients with history of recurrent acute chest syndrome tend to have lower TLC consistent with pulmonary fibrosis/restrictive disease similar to the restrictive lung disease in patients without SCD [29].

\subsection{Obstructive Sleep Apnea}

Obstructive sleep apnea (OSA) is recurrent off (stopping) and on (restarting) breathing during sleep. It occurs when the muscles that support the soft tissues of the throat, such as the tongue and soft palate, temporarily relax and also when there is lymphoid proliferation. When these muscles relax, the airway is narrowed or closed, and breathing is momentarily cut off. Signs of OSA include snoring, morning headache, daytime sleepiness, etc. It is more common (about 4 times) in children with SS than in controls. Treatment includes continuous positive airway pressure (CPAP) machine and surgery in severe cases [30, 31].

\subsection{Pulmonary Hypertension}

Pulmonary hypertension is increased blood pressure in the pulmonary vasculature (both micro \& macro vasculature). Clinical picture includes dyspnea, palpitations, pain (chest and abdomen), syncope, cyanosis, edema, fatigue and heart failure. The World Health Organization (WHO) classifies pulmonary hypertension into five groups as shown in Table 3. Among these the 
pulmonary arterial hypertension $(\mathrm{PAH})$ and the pulmonary venous hypertension $(\mathrm{PVH})$ are the most common and most important in SCD.

The pathophysiology of PAH includes two mechanisms: vascular obstruction and intimal hyperplasia. The vasoconstriction is due to decreased nitric oxide bioavailability and increased production of vaso-constrictors such as endothelin [32]. Intimal hyperplasia is the result of the hypoxia response pathway [33]. Specifically, hypoxia induced factors $\alpha$ and $\beta$ (HIF- $\alpha$ and HIF- $\beta$ ) translocate to the nucleus across the cell membrane. The $\alpha / \beta$ complex activates the transcription of genes that increase cell proliferation and inflammation thus causing intimal hyperplasia and vaso-occlusion. The PVH, on the other hand, is due to left ventricular failure.

Pulmonary hypertension is technically defined by a mean pulmonary artery pressure (MPAP) $\geq$ $25 \mathrm{mmHg}$ which can be determined by echocardiography. In order to determine whether it is PAH or PVH, however, depends on the mean pulmonary capillary wedge pressure which cannot be determined by echocardiography but requires right heart catheterization (RHC). As shown in Table 4 PAH is characterized by MPAP $\geq 25 \mathrm{mmHg}$ and capillary wedge pressure $\leq 15 \mathrm{mmHg}$ whereas in PVH the capillary wedge pressure is $>15 \mathrm{mmHg}$.

Treatment of pulmonary hypertension depends on its etiology. Thus the treatment of PVH targets the management of left ventricular failure. Treatment of PAH includes the use of vasodilators. This worked in PAH in the general population but not in PAH in patients with SCD. For now management of PAH in SCD includes blood transfusion and hydroxyurea. More studies and controlled trials are needed to determine the appropriate treatment of the PAH of SCD. 


\section{Fibromyalgia, Rheumatoid Arthritis and Osteoarthritis}

The signs and symptoms of these disorders overlap with those of SCD especially in the case of fibromyalgia [34]. The occurrence of fibromyalgia may be mistaken for sickle cell pain. Fibromyalgia pain is typically persistent, severe, and disabling and afflicts females approximately five times more often than males $[35,36]$. In the United States, approximately 5 to 6 million individuals suffer from fibromyalgia. The characteristic patient is a woman 20 to 45 years of age who has diffuse chronic pain and chronic fatigue syndrome. Physical examination reveals no abnormalities, except for scattered tender points that are painful on palpation.

Traditionally, the pain is subdivided into localized and diffuse. Interestingly, fibromyalgia is not an inflammatory disease, and primary central sensitization is thought to be the pathophysiologic mechanism of pain [37]. In one retrospective study [34], a rheumatologist reviewed the charts of nine patients with SCD and eleven inpatients with other forms of anemia and assessed them for fibromyalgia. Eight of nine patients with SCD fulfilled the classification criteria for fibromyalgia, compared to one of eleven patients without $\operatorname{SCD}(\mathrm{P}<0.001)$. Except for this retrospective chart review, fibromyalgia has not been reported in association with SCD. Again, its occurrence may be mistaken for sickle cell pain. Those patients with intractable chronic VOC pain may suffer from chronic fibromyalgia with superimposed acute VOCs. Such a possible combination needs further explanation and study. Thorough history, physical exam and radiological studies could differentiate rheumatoid arthritis and osteoarthritis from sickle cell pain.

\section{Gout}

The increased purine turnover of accelerated erythropoiesis in SS causes increased production 
of uric acid [38] in amounts proportional to the severity of hemolysis. However, in most patients, increased production of uric acid is balanced by increased renal excretion [39, 40].

Consequently, most patients with SCD have a normal or moderately elevated serum uric acid level. Reports of clinical gout are infrequent [41-44] but usually involve the knees, wrists, and small finger joints rather than the big toe, as is typical of classical gout [45]. Gout may be underdiagnosed in a disease associated with recurrent joint pain and may be mistaken for the usual VOC of SCD. Hyperuricemia alone is not sufficient to establish diagnosis, which requires the demonstration of uric acid crystals in joint fluid [46, 47].

\section{Hepatitis}

\subsection{Viral Hepatitis}

The clinical, laboratory, and liver findings of patients with SS and viral hepatitis appear to be more complicated, more prolonged, and associated with significantly greater bilirubin levels than in control groups [45, 48]. Viral hepatitis occurs as frequently as in the general population [49]. Hepatitis C, and to a lesser extent hepatitis B, occur more often because of blood-product exposure. Improved blood-product testing has reduced the incidence of these infections, but they still occur. Patients with chronic hepatitis B or hepatitis C should be treated as any other patients. There has been some concern regarding the use of ribavirin because it may cause hemolytic anemia. If a patient on ribavirin develops worsening anemia, placing the patient on chronic transfusion would allow therapy to continue and would decrease sickle cell and anemia symptoms. A recent article reported good results in treating patients with SCD for chronic hepatitis C [50]. Liver transplant is as successful in patients with SCD as in other patients needing allograft liver transplant [51-54]. 


\subsection{Autoimmune Hepatitis}

Autoimmune hepatitis has been reported in patients with SCD [55-58]. Associated features of autoimmune hepatitis include rashes, skin ulcers, and joint disease. The etiology, natural course, and treatment of autoimmune hepatitis in SCD are unclear. If a patient has persistent liver symptoms and antibody titers to smooth muscles, a therapeutic trial of prednisone and azathioprine may be warranted. Referral to a hepatologist is indicated.

\section{Malignant Disorders}

\subsection{Solid Tumors}

Solid tumors have been reported in patients with SCD including SS and hemoglobin (Hb) SC disease. Reported cancer included alveolar cell carcinoma [59], breast cancer [60-63], pheochromocytoma [64-66], renal medullary carcinoma [67, 68], testicular carcinoma, gastric cancer and poorly differentiated adenocarcinoma of unknown origin [63]. The age range of adult patients with solid tumors was $18-79$ years with a mean age of 28.8 years. The mean age at death due to cancer, survival rate and the cancer incidence rate are not well defined due to the relatively small number of patients reported. In one institution the estimated cancer incidence rate was 1,74 per 1000 patient years and the mortality rate was 1.04 per 1000 patient years [63]. Renal medullary carcinoma was reported more often in sickle cell trait than in SCD [69-73]. Surprisingly, colon cancer and gynecologic cancers (ovarian, cervical and endometrial) were not reported in SCD or the author could not find them.

There is concern that long term use of hydroxyurea may be associated with increased incidence of malignancy. Moreover, the use of allogenic stem cell transplantation is on the increase and 
this also is a risk factor for the development of cancer [74]. To date however, there is no evidence that either of these therapeutic approaches are associated with malignancy.

\subsection{Hematologic Malignancy}

Acute leukemia, chronic leukemia, Hodgkin and non-Hodgkin lymphoma have been reported in patients with SCD [75-78]. Hematologic malignancies tend to be more common in children than in adults with SCD with the exception of multiple myeloma. The combination of SCD and multiple myeloma is a bad combination. Both are characterized by hyperviscosity, renal failure, bone involvement, and sepsis, due to suppressed immunity [79-84].

Unfortunately, the diagnosis of multiple myeloma may be missed initially since the presenting signs and symptom of multiple myeloma are often attributed to SCD.

\section{Obesity, Diabetes and Hypertension}

Obesity, diabetes and hypertension is a triad that is common in the general population at large in the USA. Obesity is the culprit of this triad that is associated with diabetes and hypertension. Obesity is a real epidemic in the US. About one third of the adult population in the US is obese (Figure 2). Effective management of obesity prevents or ameliorates diabetes and hypertension.

\subsection{Definition of Obesity}

Obesity $[85,86]$ is best defined and diagnosed by the determination of the body mass index (BMI) which is equal to body weight in $\mathrm{Kg}$ divided by the square of height in meters [BMI = $\mathrm{kg} / \mathrm{m}^{2}$ ]. The normal BMI is between 18.5 and 25. Classification of the BMI according to the

WHO is shown in Table 5. BMI and survival are related $[87,88]$. In addition to diabetes and 
hypertension, other comorbidities associated with obesity include cardiovascular disease, sleep apnea, stroke and dementia [88, 89].

Obesity is on the rise in patients with SCD especially those with Hb SC disease. There are anecdotes of a few women aged 40-45 years with $\mathrm{Hb}$ SC disease whose BMI was > 40 [90]. The prevalence of overweight/obesity in patients with SCA or Hb SC disease is not well documented. Although resting energy expenditure in SCD is higher than in normal individuals which could protect or minimize overweight/obesity, the BMI of patients with SCD, especially with $\mathrm{Hb} \mathrm{SC}$ disease seems to be following the same trend in the general population [91].

\subsection{Management of obesity}

The US Preventive Services Task Force (USPSTF) recommends that providers screen all adults for obesity and to refer patients with BMI > 30 to multicomponent interventions (strong recommendation, moderate evidence). Dietary management entails the determination of the daily calorie requirement for each patient [92]. This includes the daily basal calorie requirement plus the additional requirement based on activity including exercise. The basal requirement depends on age, sex, height and weight and the requirement for activity depends whether it is mild moderate or extensive [21]. This is best determined by a nutritionist/physiologist. The patient, then, should keep record of the calorie intake so it does not exceed the daily requirement. The fact that all food items have labels listing the nutritional facts that include calories per serving, cholesterol, salt, etc. simplifies the dietary approach for the management of obesity. This approach, however, requires patient and adherence to the recommendations. 
If dietary management fails, bariatric surgical treatment may be considered [93, 94]. The most frequently used surgical procedures for bariatric surgery include the Roux-en-Y gastric bypass and Sleeve Gastrectomy.

\section{Ophthalmological Comorbidities}

\subsection{Cataract}

Cataract is progressive clouding of the lens of the eye resulting in blurred vision. It could be unilateral or bilateral. The word cataract is derived from the Latin cataracta meaning waterfall, cascade or white water. The simile indicates the difficulty to see clearly through waterfalls. Typically, cataract occur in older patients [6] and hence, are often referred to as senile cataracts.

Cataracts in SCD were first reported in 1976 in two patients while receiving sodium cyanate for treatment of SS [95]. Ophthalmologic examination revealed bilateral posterior subcapsular cataracts in both patients. After discontinuation of cyanate therapy the lens opacities regressed in one of the patients. The first case of senile cataract was first reported in a 62-year-old man with SS [96]. His cataracts were also bilateral and posterior subcapsular. Cataract extraction from both eyes showed clear but thick, tenacious and mucoid aqueous humor unlike that seen in other senile cataracts without SCD. Like other ophthalmologic complications, cataracts seem to be more common in Hb SC disease than SS [97].

\subsection{Glaucoma}


The glaucoma reported in SCD is mostly secondary glaucoma [98-105]. Causes of secondary glaucoma include medications, trauma, physical injury, inflammation or eye surgery. In SCD, glaucoma is most often associated with traumatic hyphemas causing obstruction of the anterior chamber outflow tract. Less often, it may be associated with retinopathy. Glaucoma has been described in both SCD and sickle cell trait.

In primary glaucoma the cause of obstruction of the aqueous humor flow is unknown. In older patients the aqueous humor flow may be less efficient leading to glaucoma. Anecdotally octogenarians with SCD and glaucoma have been described [6] but it is not known if their glaucoma is primary or secondary.

\section{Orofacial Comorbidities}

Certain complications and comorbidities of SCD have not been well studied. These include, among other systems, cranio-orbital, orofacial, dental and otologic complications. The prevalence, clinical manifestations, management and the association of these with other complication of SCD are poorly understood. The scanty data on these complications of SCD include observational studies and case reports. The highlights of these as they may pertain to older patients with SCD will be summarized in this review.

\subsection{Dental comorbidities}

Table 6 lists the dental comorbidities described in patients with SCD [106-113]. Caries are the most common dental comorbidity globally and in patients with SCD. Whether some of these complications are pathophysiologic manifestations of SCD or comorbidities in addition to SCD is controversial [114-116]. Some authors indicate that poor oral hygiene maintenance may be the 
major cause of dental complications in SCD. Thus, it is imperative the dental follow-ups every 6 months should be emphasized for patients with SCD. Aseptic necrosis of teeth has been described in some patients. The hallmark of this complication is the presence of dental pain in the absence of any dental pathology [117-119].

A recent Cochrane review of guidelines for the treatment of dental complications in SCD found that such guidelines are not available and unclear [112].

\subsection{Temporomandibular Disorder}

A few patients with SCD have been reported with avascular necrosis of the temporomandibular joint [120-123]. This seems to be different from the classical temporomandibular disorder, or at least a rare cause of temporomandibular disorder.

\section{Otologic Comorbidities}

\subsection{Deafness}

Hearing loss or deafness has been well described in patients with SCD. It is usually sensorineural in nature. It could be unilateral or bilateral with sudden or gradual onset. Possible etiologies include infection especially in children, tumors (neuroma or Schwannoma), labyrinthine hemorrhage or labyrinthitis ossificans [124-128].

Unlike the dental complications, three prospective, controlled, cross-sectional studies reported the effect of age on the prevalence of inner ear involvement. The first found mild sensory neural hearing loss (SNHL) in three of 80 (3.8\%) Nigerian children with SS 4 - 15 years old [129]. In the second study, the SNHL occurred in seven of 52 (13.5\%) Nigerian children with SS 6 - 19 
years old [130]. The third study was of 167 Nigerian adults $15-56$ years of age with SS in whom the prevalence of SNHL was 66\% [131]. Similarly, in a Brazilian prospective controlled study [132], the prevalence of SNHL in 28 adults with SS was $21.4 \%$ compared to $3.6 \%$ in control subjects $(\mathrm{P}=0.05)$; moreover, the prevalence was greater among patients $\geq 25$ years old than younger patients ( $\mathrm{P}<$ aenso0.05). In Guadeloupe (France), the prevalence of SNHL was 47.22\% among patients with $\mathrm{Hb}$ SC disease and $43.5 \%$ among those with SS, and the majority of the patients had the Benin $\beta$ s haplotype [133]. The prevalence in these countries is greater than what has been reported in the UK and US [134, 135]. Moreover, in Nigeria, Brazil, and Guadeloupe (France), the prevalence of SNHL was relatively high in control groups, albeit lower than that among patients with SCD; in comparison, the prevalence of SNHL in the control group of the UK study was nil. These findings suggest that the tropics may be a predisposing factor for SNHL, possibly as a malarial effect in some countries $[135,136]$. SNHL is bilateral in most patients with SCD; when it is unilateral, it is more frequent on the left side. It seems to be more common in males and in patients with $\mathrm{Hb}$ SC disease [129, 131, 133-135, 137].

\subsection{Tinnitus}

Tinnitus is the perception of sound in one or both ears the source of which is not external. It is often descried, among other things, as buzzing, ringing, humming, hissing, etc. It usually lasts for a relatively short period but it may recur on and off. In a few persons it may be prolonged. Tinnitus has been described in patients with SCD but always in the presence of deafness [132, 134, 138].

\section{Vaccination}


The following vaccines are recommended for persons in the general population aged 60 years or older:

1. Influenza vaccine annually

2. Shingles (Herpes zoster ) vaccine once

3. DPT (Diphtheria, pertussis and tetanus vaccine once even if taken before

4. Anti-pneumococcal vaccines at least once, preferably every 5-7 years:
a. PCV13
b. PPSV23

By analogy the same vaccines should be given to patients with SCD preferably once they reach the age of 50 years. To date, however, there are no specific recommendations for vaccinating older patients with SCD.

\section{Conclusion}

The advent of newborn screening, antibiotic prophylaxis, better vaccines, safer blood transfusion, iron chelation and hydroxyurea improved the survival of patients with SCD. This improvement, however, introduced a third dimension of SCD, namely the older and elderly patients with SCD. There is concern that the improved survival may be offset by the comorbidities of the older patients in the general population. Thus it is important that providers become aware of these comorbidities and how to differentiate them from the complications of the disease so that appropriate therapies can be given.

\section{Legend to Figures:}


Figure 1: Life expectancy of patients with sickle cell disease from 1900 through 2010. The arrow indicates the infliction point where life expectancy of patients with sickle cell disease began to increase. Adapted from National Heart, Lung, and Blood Institute. Sickle cell research for treatment and cure (NIH Publication No. 02-5214). Bethesda, MD: US Department of Health and Human Services.

Figure 2: This figure compares obesity rates from various countries.

https://commons.wikimedia.org/wiki/File:Obesity_country_comparison___path.svg

\section{References:}

[1] Platt OS, Brambilla DJ, Rosse WF, Milner PF, Castro O, Steinberg MH, et al. Mortality in sickle cell disease. Life expectancy and risk factors for early death. N Engl J Med. 1994;330(23):1639-44.

[2] Steinberg MH, McCarthy WF, Castro O, Ballas SK, Armstrong FD, Smith W, et al. The risks and benefits of long-term use of hydroxyurea in sickle cell anemia: A 17.5 year follow-up. Am J Hematol. 2010;85(6):403-8.

[3] Wierenga KJ, Hambleton IR, Lewis NA. Survival estimates for patients with homozygous sickle-cell disease in Jamaica: a clinic-based population study. Lancet. 2001;357(9257):680-3.

[4] Le PQ, Gulbis B, Dedeken L, Dupont S, Vanderfaeillie A, Heijmans C, et al. Survival among children and adults with sickle cell disease in Belgium: Benefit from hydroxyurea treatment. Pediatr Blood Cancer. 2015;62(11):1956-61.

[5] Steinberg MH, Ballas SK, Brunson CY, Bookchin R. Sickle cell anemia in septuagenarians. Blood. 1995;86(10):3997-8.

[6] Ballas SK, Pulte ED, Lobo C, Riddick-Burden G. Case series of octogenarians with sickle cell disease. Blood. 2016.

[7] Forman DE, Berman AD, McCabe CH, Baim DS, Wei JY. PTCA in the elderly: the "young-old" versus the "old-old". J Am Geriatr Soc. 1992;40(1):19-22.

[8] Zizza CA, Ellison KJ, Wernette CM. Total water intakes of community-living middle-old and oldest-old adults. J Gerontol A Biol Sci Med Sci. 2009;64(4):481-6.

[9] Grissinger M. How to prevent medication errors in long-term care: part 2. Consult Pharm. 2007;22(8):646-58.

[10] Thomas H. Assessing and managing depression in older people. Nurs Times. 2013;109(43):16-8.

[11] Liptzin B. Introduction: The Challenges of Treating Older Adults. Psychiatric Times. 2014(October 30).

[12] Fine PG. Pharmacological management of persistent pain in older patients. Clin J Pain. 2004;20(4):220-6.

[13] Giamberardino MA, Jensen TS, editors. Pain comorbidities. Seattle: IASP Press; 2012. 
[14] Aliyu ZY, Kato GJ, Taylor Jt, Babadoko A, Mamman AI, Gordeuk VR, et al. Sickle cell disease and pulmonary hypertension in Africa: a global perspective and review of epidemiology, pathophysiology, and management. Am J Hematol. 2008;83(1):63-70.

[15] Bagasra O, Steiner RM, Ballas SK, Castro O, Dornadula G, Embury S, et al. Viral burden and disease progression in HIV-1-infected patients with sickle cell anemia. Am J Hematol. 1998;59(3):199-207.

[16] Obaro S. Does sickle cell disease protect against HIV/AIDS? Sex Transm Infect. 2012;88(7):533.

[17] Segbena AY, Prince-David M, Kagone TS, Dagnra AY. Human immunodeficiency virus, hepatitis $\mathrm{C}$ virus and hepatitis $\mathrm{B}$ viruses in patients with sickle-cell disease in Togo.

Transfus Clin Biol. 2005;12(6):423-6.

[18] Sellier P, Masson E, Zini JM, Simoneau G, Magnier JD, Evans J, et al. Disease progression in HIV-1-infected patients heterozygous for the sickle hemoglobin gene. AIDS. 2009;23(17):2362-4.

[19] Steiner RM, Ballas SK. Human immunodeficiency virus (HIV I) infection in sickle cell anemia: prevalence and outcome. National Sickle Cell Program, 21st Annual Meeting Book of Abstracts; Mobile, Alamba1996. p. 059.

[20] O'Neill WM, Sherrard JS. Pain in human immunodeficiency virus disease: a review. Pain. 1993;54(1):3-14.

[21] Ballas SK. Sickle Cell Pain, 2nd Edition. Washington DC: International Association for the Study of Pain; 2014.

[22] Terry SI, Rajendran A, Hanchard B, Serjeant GR. Ulcerative colitis in sickle cell disease. J Clin Gastroenterol. 1987;9(1):55-7.

[23] Azar JM, Darbari DS, Meier ER, Conklin LS, Darbari A. Inflammatory bowel disease in sickle cell disease: diagnostic and treatment challenges. J Pediatr Gastroenterol Nutr. 2014;59(5):e47.

[24] National Asthma Education and Prevention Program Expert Panel Report 3: Guidelines for the Diagnosis and Management of Asthma NIH Publication 07-4051 Bethseda, MD: National Heart Lung and Blood Institute; 2007

[25] Newaskar M, Hardy KA, Morris CR. Asthma in sickle cell disease. ScientificWorldJournal. 2011;11:1138-52.

[26] Boyd JH, Macklin EA, Strunk RC, DeBaun MR. Asthma is associated with increased mortality in individuals with sickle cell anemia. Haematologica. 2007;92(8):1115-8.

[27] Anim SO, Strunk RC, DeBaun MR. Asthma morbidity and treatment in children with sickle cell disease. Expert Rev Respir Med. 2011;5(5):635-45.

[28] Guarascio AJ, Ray SM, Finch CK, Self TH. The clinical and economic burden of chronic obstructive pulmonary disease in the USA. Clinicoecon Outcomes Res. 2013;5:235-45.

[29] Klings ES, Wyszynski DF, Nolan VG, Steinberg MH. Abnormal pulmonary function in adults with sickle cell anemia. Am J Respir Crit Care Med. 2006;173(11):1264-9.

[30] Kemp JS. Obstructive sleep apnea and sickle cell disease. J Pediatr Hematol Oncol. 1996;18(2):104-5.

[31] Kaleyias J, Mostofi N, Grant M, Coleman C, Luck L, Dampier C, et al. Severity of obstructive sleep apnea in children with sickle cell disease. J Pediatr Hematol Oncol. 2008;30(9):659-65.

[32] Gaine S. Pulmonary hypertension. JAMA. 2000;284(24):3160-8.

[33] Simon MC. The Hypoxia Response Pathways - Hats Off! N Engl J Med. 2016. 
[34] Schlesinger N. Clues to pathogenesis of fibromyalgia in patients with sickle cell disease. J Rheumatol. 2004;31(3):598-600.

[35] Campos RP, Vazquez MI. The impact of fibromyalgia on health-related quality of life in patients according to age. Rheumatol Int. 2013;33:1419-24.

[36] Roehrs T, Diederichs C, Gillis M, Burger AJ, Stout RA, Lumley MA, et al. Nocturnal sleep, daytime sleepiness and fatigue in fibromyalgia patients compared to rheumatoid arthritis patients and healthy controls: a preliminary study. Sleep Med. 2013;14:109-15.

[37] Woolf CJ. Central sensitization: implications for the diagnosis and treatment of pain. Pain. 2011;152(3 Suppl):S2-15.

[38] Crosby WH. The metabolism of hemoglobin and bile pigment in hemolytic disease. Am J Med. 1955;18(1):112-22.

[39] Diamond HS, Meisel A, Sharon E, Holden D, Cacatian A. Hyperuricosuria and increased tubular secretion of urate in sickle cell anemia. Am J Med. 1975;59(6):796-802.

[40] Diamond HS, Meisel AD, Holden D. The natural history of urate overproduction in sickle cell anemia. Ann Intern Med. 1979;90(5):752-7.

[41] Bileckot R, Ntsiba H, Nzamba B. Gout secondary to sickle cell anemia. A new case. Presse Med. 1994;23(23):1095.

[42] Espinoza LR, Spilberg I, Osterland CK. Joint manifestations of sickle cell disease. Medicine (Baltimore). 1974;53(4):295-305.

[43] Leff RD, Aldo-Benson MA, Fife RS. Tophaceous gout in a patient with sickle cellthalassemia: case report and review of the literature. Arthritis Rheum. 1983;26(7):928-9.

[44] Rothschild BM, Sienknecht CW, Kaplan SB, Spindler JS. Sickle cell disease associated with uric acid deposition disease. Ann Rheum Dis. 1980;39(4):392-5.

[45] Serjeant G. Sickle cell disease, 2nd ed. Oxford: Oxford University Press; 1992.

[46] Arlet JB, Ribeil JA, Chatellier G, Pouchot J, de Montalembert M, Prie D, et al. Hyperuricemia in sickle cell disease in France. Rev Med Interne. 2012;33(1):13-7.

[47] Reynolds MD. Gout and hyperuricemia associated with sickle-cell anemia. Semin Arthritis Rheum. 1983;12(4):404-13.

[48] Barrett-Connor E. Sickle cell disease and viral hepatitis. Ann Intern Med. 1968;69:51727.

[49] Hasan MF, Marsh F, Posner G, Bellevue R, Dosik H, Suatengco R, et al. Chronic hepatitis C in patients with sickle cell disease. Am J Gastroenterol. 1996;91(6):1204-6.

[50] Ancel D, Amiot X, Chaslin-Ferbus D, Hagege I, Garioud A, Girot R, et al. Treatment of chronic hepatitis $\mathrm{C}$ in sickle cell disease and thalassaemic patients with interferon and ribavirin. Eur J Gastroenterol Hepatol. 2009;21(7):726-9.

[51] Emre S, Kitibayashi K, Schwartz ME, Ahn J, Birnbaum A, Thung SN, et al. Liver transplantation in a patient with acute liver failure due to sickle cell intrahepatic cholestasis. Transplantation. 2000;69(4):675-6.

[52] Emre S, Schwartz ME, Shneider B, Hojsak J, Kim-Schluger L, Fishbein TM, et al. Living related liver transplantation for acute liver failure in children. Liver Transpl Surg. 1999;5(3):161-5.

[53] Gilli SC, Boin IF, Sergio Leonardi L, Luzo AC, Costa FF, Saad ST. Liver transplantation in a patient with $\mathrm{S}$ (beta)o-thalassemia. Transplantation. 2002;74(6):896-8.

[54] van den Hazel SJ, Metselaar HJ, Tilanus HW, JN IJ, Groenland TH, Visser L, et al. Successful liver transplantation in a patient with sickle-cell anaemia. Transpl Int. 2003;16(6):434-6. 
[55] Chuang E, Ruchelli E, Mulberg AE. Autoimmune liver disease and sickle cell anemia in children: a report of three cases. J Pediatr Hematol Oncol. 1997;19(2):159-62.

[56] el Younis CM, Min AD, Fiel MI, Klion FM, Thung SN, Faire B, et al. Autoimmune hepatitis in a patient with sickle cell disease. Am J Gastroenterol. 1996;91(5):1016-8.

[57] Kordes U, Schneppenheim R, Briem-Richter A, Scherpe S, Schafer HJ. Parvovirus B19 infection and autoimmune hepatitis in a child with sickle cell anemia. Pediatr Blood Cancer. 2011;56(2):323-4.

[58] Lykavieris P, Benichou JJ, Benkerrou M, Feriot JP, Bernard O, Debray D. Autoimmune liver disease in three children with sickle cell disease. J Pediatr Gastroenterol Nutr. 2006;42(1):104-8.

[59] Labi M, Haponik EF, Welsh RA, Summer WR. Alveolar cell carcinoma complicating sickle cell anemia: a chance occurrence? Am J Hematol. 1989;32(3):222-5.

[60] Adebamowo CA, Akang EE, Ezeome ER. Carcinoma of the breast in a sickle cell disease patient: case report. East Afr Med J. 1996;73(7):489-90.

[61] Gupta E, Guthrie T. Breast cancer in sickle cell disease. Breast J. 2012;18(6):647-9.

[62] Al Zaman AS. Breast cancer in patients with sickle cell disease can be treated safely with weekly paclitaxel. Saudi Med J. 2013;34(2):199-201.

[63] Dawkins FW, Kim KS, Squires RS, Chisholm R, Kark JA, Perlin E, et al. Cancer incidence rate and mortality rate in sickle cell disease patients at Howard University Hospital: 1986-1995. Am J Hematol. 1997;55(4):188-92.

[64] Browne I, Brady I, Hannon V, McKeating K. Anaesthesia for phaeochromocytoma and sickle cell disease in pregnancy. Int J Obstet Anesth. 2005;14(1):66-9.

[65] Donnelly JC, Cooley SM, O'Connell MP, Murphy JF, Keane DP. Pheochromocytoma, sickle cell disease and pregnancy: a case report. J Matern Fetal Neonatal Med. 2003;14(5):353-5.

[66] Fisher EA, Hubbard TW, Byrd RL, Solhaug MJ. Management of pheochromocytoma in sickle cell disease: case report. Va Med. 1988;115(2):80-2.

[67] Sathyamoorthy K, Teo A, Atallah M. Renal medullary carcinoma in a patient with sicklecell disease. Nat Clin Pract Urol. 2006;3(5):279-83; quiz 89.

[68] Marsh A, Golden C, Hoppe C, Quirolo K, Vichinsky E. Renal medullary carcinoma in an adolescent with sickle cell anemia. Pediatr Blood Cancer. 2014;61(3):567.

[69] Smith NE, Deyrup AT, Marino-Enriquez A, Fletcher JA, Bridge JA, Illei PB, et al. VCLALK renal cell carcinoma in children with sickle-cell trait: the eighth sickle-cell nephropathy? Am J Surg Pathol. 2014;38(6):858-63.

[70] Nemoto R, Satou S, Miyagawa I, Koiso K. Inhibition by a new bisphosphonate $(\mathrm{AHBuBP})$ of bone resorption induced by the MBT-2 tumor of mice. Cancer. 1991;67(3):643-8.

[71] Daher P, Bourgi A, Riachy E, Khoury A, Rehayem C, Sader-Ghorra C. Renal medullary carcinoma in a white adolescent with sickle cell trait. J Pediatr Hematol Oncol. 2014;36(5):e285-9.

[72] Shetty A, Matrana MR. Renal medullary carcinoma: a case report and brief review of the literature. Ochsner J. 2014;14(2):270-5.

[73] Marino-Enriquez A, Ou WB, Weldon CB, Fletcher JA, Perez-Atayde AR. ALK rearrangement in sickle cell trait-associated renal medullary carcinoma. Genes Chromosomes Cancer. 2011;50(3):146-53. 
[74] Schultz WH, Ware RE. Malignancy in patients with sickle cell disease. Am J Hematol. 2003;74(4):249-53.

[75] Wilson S. Acute leukemia in a patient with sickle-cell anemia treated with hydroxyurea. Ann Intern Med. 2000;133(11):925-6.

[76] Stricker RB, Linker CA, Crowley TJ, Embury SH. Hematologic malignancy in sickle cell disease: report of four cases and review of the literature. Am J Hematol. 1986;21(2):22330 .

[77] Phillips G, Jr., Hartman J, Kinney TR, Sokal JE, Kaufman RE. Chronic granulocytic leukemia in a patient with sickle cell anemia. Am J Med. 1988;85(4):567-9.

[78] Morabito F, Callea V, Brugiatelli M, D'Ascola D, Palazzolo A, Neri A. Non-Hodgkin's lymphoma associated with sickle cell disease: a case report. Tumori. 1987;73(5):523-4.

[79] Anderson IS, Yeung KY, Hillman D, Lessin LS. Multiple myeloma in a patient with sickel cell anemia. Interacting effects on blood viscosity. Am J Med. 1975;59(4):568-74.

[80] Kaloterakis A, Filiotou A, Konstantopoulos K, Rombos Y, Bossinakou I, Hadziyannis S. Multiple myeloma in sickle cell syndromes. Haematologia (Budap). 2001;31(2):153-9.

[81] Lemonne N, Connes P, Romana M, Vent-Schmidt J, Bourhis V, Lamarre Y, et al. Increased blood viscosity and red blood cell aggregation in a patient with sickle cell anemia and smoldering myeloma. Am J Hematol. 2012;87(11):E129.

[82] Martinez-Maldonado M. The kidney in sickle cell disease and multiple myeloma. Perspect Nephrol Hypertens. 1976;3:77-93.

[83] Nicoleau A, Kaplan B, Balzora JD. Hemoglobin SC and multiple myeloma. Am J Hematol. 1999;60(3):250-1.

[84] Sarma PS, Viswanathan KA, Mukherjee MM. Multiple myeloma in a patient with sickle cell anaemia. J Assoc Physicians India. 1986;34(12):877-8.

[85] Akodu SO, Diaku-Akinwumi IN, Njokanma OF. Obesity--does it occur in Nigerian children with sickle cell anemia. Pediatr Hematol Oncol. 2012;29(4):358-64.

[86] Koduri PR, Agbemadzo B, Nathan S. Hemoglobin S-C disease revisited: clinical study of 106 adults. Am J Hematol. 2001;68(4):298-300.

[87] Manson JE, Stampfer MJ, Hennekens CH, Willett WC. Body weight and longevity. A reassessment. JAMA. 1987;257(3):353-8.

[88] Twig G, Yaniv G, Levine H, Leiba A, Goldberger N, Derazne E, et al. Body-Mass Index in 2.3 Million Adolescents and Cardiovascular Death in Adulthood. N Engl J Med. 2016;374(25):2430-40.

[89] Mokhlesi B, Ayas NT. Cardiovascular Events in Obstructive Sleep Apnea - Can CPAP Therapy SAVE Lives? N Engl J Med. 2016;375(10):994-6.

[90] Ballas SK. The Sixth Vital Sign: Body Mass Index in Patients With Sickle Cell Disease. J Clin Med Res. 2017;9(10):889-90.

[91] Buchowski MS, Simmons LA, Chen KY, Flakoll PJ, Mellen BG, Turner EA. Plasma leptin association with body composition and energy expenditure in sickle cell disease. J Am Coll Nutr. 2000;19(2):228-36.

[92] Ballas S. K. Chapter 13: Diet, Fluids and Sickle Cell Pain. Sickle Cell Pain, 2nd edition. Washington DC: International Association for the Study of Pain; 2014. p. 431-57.

[93] Merino I, Borrat X, Balust J, Delgado S, Lacy AM, Vidal J, et al. Rhabdomyolysis after bariatric surgery: a potentially fatal complication. Br J Anaesth. 2009;102(2):283-4.

[94] Torpy JM, Burke A, Glass RM. JAMA patient page. Bariatric surgery. JAMA. 2005;294(15):1986. 
[95] Nicholson DH, Harkness DR, Benson WE, Peterson CM. Cyanate-induced cataracts in patients with sickle-cell hemoglobinopathies. Arch Ophthalmol. 1976;94(6):927-30.

[96] Lorenzen K, Rao KP, Patel AR, Desnick J. Sickle-cell anaemia and viscid aqueous humor associated with senile cataracts. Lancet. 1979;1(8122):922-3.

[97] Osafo-Kwaako A, Kimani K, Ilako D, Akafo S, Ekem I, Rodrigues O, et al. Ocular manifestations of sickle cell disease at the Korle-bu Hospital, Accra, Ghana. Eur J Ophthalmol. 2011;21(4):484-9.

[98] Benner JD. Transcorneal oxygen therapy for glaucoma associated with sickle cell hyphema. Am J Ophthalmol. 2000;130(4):514-5.

[99] Liebmann JM. Management of sickle cell disease and hyphema. J Glaucoma. 1996;5(4):271-5.

[100] Bergren RL, Brown GC. Neovascular glaucoma secondary to sickle-cell retinopathy. Am J Ophthalmol. 1992;113(6):718-9.

[101] Greenwald MJ, Crowley TM. Sickle cell hyphema with secondary glaucoma in a nonblack patient. Ophthalmic Surg. 1985;16(3):170-1.

[102] Steinmann W, Stone R, Nichols C, Werner E, Schweitzer J, Keates E, et al. A casecontrol study of the association of sickle cell trait and chronic open-angle glaucoma. Am J Epidemiol. 1983;118(2):288-93.

[103] Goldberg MF. Sickled erythrocytes, hyphema, and secondary glaucoma: I. The diagnosis and treatment of sickled erythrocytes in human hyphemas. Ophthalmic Surg. 1979;10(4):17-31.

[104] Goldberg MF. The diagnosis and treatment of secondary glaucoma after hyphema in sickle cell patients. Am J Ophthalmol. 1979;87(1):43-9.

[105] Goldberg MF, Dizon R, Raichand M. Sickled erythrocytes, hyphema, and secondary glaucoma: II. Injected sickle cell erythrocytes into human, monkey, and guinea pig anterior chambers: the induction of sickling and secondary glaucoma. Ophthalmic Surg. 1979;10(4):32-51.

[106] Acharya S. Oral and Dental Considerations in Management of Sickle Cell Anemia. Int J Clin Pediatr Dent. 2015;8(2):141-4.

[107] Amoah KG, Newman-Nartey M, Ekem I. The Orthodontic Management of an Adult with Sickle Cell Disease. Ghana Med J. 2015;49(3):214-8.

[108] Costa CP, Aires BT, Thomaz EB, Souza Sde F. Dental care provided to sickle cell anemia patients stratified by age: A population-based study in Northeastern Brazil. Eur J Dent. 2016;10(3):356-60.

[109] Costa CP, Carvalho HL, Souza Sde F, Thomaz EB. Is sickle cell anemia a risk factor for severe dental malocclusion? Braz Oral Res. 2015;29.

[110] de Carvalho HL, Thomaz EB, Alves CM, Souza SF. Are sickle cell anaemia and sickle cell trait predictive factors for periodontal disease? A cohort study. J Periodontal Res. 2016;51(5):622-9.

[111] Fernandes ML, Kawachi I, Correa-Faria P, Pattusi MP, Paiva SM, Pordeus IA. Caries prevalence and impact on oral health-related quality of life in children with sickle cell disease: cross-sectional study. BMC Oral Health. 2015;15:68.

[112] Mulimani P, Ballas SK, Abas AB, Karanth L. Treatment of dental complications in sickle cell disease. Cochrane Database Syst Rev. 2016;4:Cd011633.

[113] Ballas SK, Lopes de Castro Lobo C, Cavalcanti WE. Dental Complications of Sickle Cell Disease. J Interdiscipl Med Dent Sci. 2014;2:6. 
[114] Costa CP, de Carvalho HL, Thomaz EB, Sousa Sde F. Craniofacial bone abnormalities and malocclusion in individuals with sickle cell anemia: a critical review of the literature. Rev Bras Hematol Hemoter. 2012;34(1):60-3.

[115] Costa CP, Thomaz EB, Souza Sde F. Association between Sickle Cell Anemia and Pulp Necrosis. J Endod. 2013;39(2):177-81.

[116] Javed F, Correa FO, Nooh N, Almas K, Romanos GE, Al-Hezaimi K. Orofacial manifestations in patients with sickle cell disease. Am J Med Sci. 2013;345(3):234-7.

[117] O'Rourke C, Mitropoulos C. Orofacial pain in patients with sickle cell disease. Br Dent J. 1990;169(5):130-2.

[118] O'Rourke CA, Hawley GM. Sickle cell disorder and orofacial pain in Jamaican patients. Br Dent J. 1998;185(2):90-2.

[119] Ferraz M, Menucci A, Lobo C, Espirito Cavalcanti W, and, Ballas SK. Aseptic Pulp Necrosis of a Tooth in Sickle Cell Anemia. J Interdiscipl Med Dent Sci. 2015;3:4.

[120] Baykul T, Aydin MA, Nasir S. Avascular necrosis of the mandibular condyle causing fibrous ankylosis of the temporomandibular joint in sickle cell anemia. J Craniofac Surg. 2004;15(6):1052-6.

[121] Caracas Mda S, Jales SP, Jales Neto LH, da Silva Castro JC, Suganuma LM, Fonseca $\mathrm{GH}$, et al. Temporomandibular joint arthritis in sickle cell disease: a case report. Oral Surg Oral Med Oral Pathol Oral Radiol. 2013;115(2):e31-5.

[122] el-Sabbagh AM, Kamel M. Avascular necrosis of temporomandibular joint in sickle cell disease. Clin Rheumatol. 1989;8(3):393-7.

[123] Mendes PH, Fonseca NG, Martelli DR, Bonan PR, de Almeida LK, de Melo LA, et al. Orofacial manifestations in patients with sickle cell anemia. Quintessence Int. 2011;42(8):701-9.

[124] Mackeith SA, Kerr RS, Milford CA. Trends in acoustic neuroma management: a 20-year review of the oxford skull base clinic. J Neurol Surg B Skull Base. 2013;74(4):194-200.

[125] Patel J, Vasan R, van Loveren H, Downes K, Agazzi S. The changing face of acoustic neuroma management in the USA: analysis of the 1998 and 2008 patient surveys from the acoustic neuroma association. Br J Neurosurg. 2014;28(1):20-4.

[126] Wikipedia editors. Tionne Watkins [Available from: http://en.wikipedia.org/wiki/Tionne_Watkins\#cite_note-15.

[127] Karanja BW, Oburra HO, Masinde P, Wamalwa D. Prevalence of hearing loss in children following bacterial meningitis in a tertiary referral hospital. BMC Res Notes. 2014;7:138.

[128] Bille J, Ovesen T. Cochlear implant after bacterial meningitis. Pediatr Int. 2014;56(3):400-5.

[129] Alabi S, Ernest K, Eletta P, Owolabi A, Afolabi A, Suleiman O. Otological findings among Nigerian children with sickle cell anaemia. Int J Pediatr Otorhinolaryngol. 2008;72(5):659-63.

[130] Mgbor N, Emodi I. Sensorineural hearing loss in Nigerian children with sickle cell disease. Int J Pediatr Otorhinolaryngol. 2004;68(11):1413-6.

[131] Onakoya PA, Nwaorgu OG, Shokunbi WA. Sensorineural hearing loss in adults with sickle cell anaemia. Afr J Med Med Sci. 2002;31(1):21-4.

[132] Piltcher O, Cigana L, Friedriech J, Ribeiro FA, da Costa SS. Sensorineural hearing loss among sickle cell disease patients from southern Brazil. Am J Otolaryngol. 2000;21(2):75-9. 
[133] Jovanovic-Bateman L, Hedreville R. Sensorineural hearing loss with brainstem auditory evoked responses changes in homozygote and heterozygote sickle cell patients in Guadeloupe (France). J Laryngol Otol. 2006;120(8):627-30.

[134] Saito N, Watanabe M, Liao J, Flower EN, Nadgir RN, Steinberg MH, et al. Clinical and radiologic findings of inner ear involvement in sickle cell disease. AJNR Am J Neuroradiol. 2011;32(11):2160-4.

[135] Ajulo SO, Osiname AI, Myatt HM. Sensorineural hearing loss in sickle cell anaemia--a United Kingdom study. J Laryngol Otol. 1993;107(9):790-4.

[136] Isaacson JE, Vora NM. Differential diagnosis and treatment of hearing loss. Am Fam Physician. 2003;68(6):1125-32.

[137] Desai P, Dejoie-Brewer M, Ballas SK. Deafness and sickle cell disease: three case reports and review of the literature. J Clin Med Res. 2015;7(3):189-92.

[138] Todd GB, Serjeant GR, Larson MR. Sensori-neural hearing loss in Jamaicans with SS disease. Acta Otolaryngol. 1973;76(4):268-72. 